\title{
Practice paper - Your Name Here: Renaming and reclaiming space. A new town centre vision within a renamed Park
}

\author{
Karen M Smith* \\ Freelance Researcher
}

\section{Introduction}

This article describes the practice, process and impact of a socially engaged arts project Your Name Here. Artist Joshua Sofaer was commissioned by the arts organisation Heart of Glass, based in St Helens. Sofaer worked in partnership with the people of St Helens and Heart of Glass. The process culminated in the naming of a new park for St Helens, and created a public renaming and reclaiming of space.

I have worked for 28 years within arts practice, and remain curious to explore the ways in which artist-led practice, participation and collaboration can develop trust, partnership and create positive change within and with communities of people. As an independent practitioner, my relationship with Heart of Glass commenced in 2014 as the organisation began to take shape. I continue to observe, research, write about, and where relevant, question the evolving practice. Exploring the making of Your Name Here in more detail gave an opportunity to reflect on the processes after they unfolded and understand more deeply why those processes are so important to be curious about, and take care of, for future practice.

This piece explores the ongoing procession of space into place via meaning making activities that are achieved through artistic practice. It investigates the processes of negotiation that took place within a mass participation arts project, and the continuation of those processes which have turned an unvalued space into a place with significant meaning to the people of St Helens. The animation of public space Your Name Here represents forms part of a new contribution to contemporary socially engaged arts practice.

\section{Context}

\section{Heart of Glass}

Heart of Glass emerged as a consortium of partners and gained funding from Arts Council England's Creative People and Places (CPP) in 2014. The project was one of 21 Creative People and Places programmes supported by Arts Council England across the country. 
p. 253. Practice paper - Your Name Here: Renaming and reclaiming space. A new town centre vision within a renamed Park

Heart of Glass, four years on, is an independently constituted organisation made with, of and for St Helens. The organisation balances the strengths that independence brings with the strengths of continuing to be a key participant in Creative People and Places action research funding. From the outset, partnerships have been critical to the success of Heart of Glass. These continue to develop as Heart of Glass becomes more embedded. The artistic programme is rooted in collaborative practice. The long-term partnership with artists as leaders remains a defining value. Heart of Glass's committed approach to artists long-term include a 12 year commitment with the artist Mark Storor, and a four year commitment to a partnership with artists Heather and Ivan Morrison.

\section{Your Name Here}

Your Name Here was an early Heart of Glass project. As a mass participation art work, it formed part of a series of commissions marking the beginning of Heart of Glass's socially engaged approach to arts participation. The instigation of Your Name Here came not from an in-depth study of the community, but from Heart of Glass's desire as commissioner and producer to articulate a possibility of what art practice might do or could be for St Helens. Heart of Glass commissioned and trusted Sofaer, a sensitive and experienced artist to be able to deliver a project that spoke to and with the people of St Helens. Heart of Glass committed to the artist rather than an idea of what the work would be. The Director of Heart of Glass, Patrick Fox, is a producer, commissioner and senior arts leader who supports artists to engage with communities of place and / or interest to create contemporary work that reflects the politics of now.

The artist Joshua Sofaer had devised three previous markedly different 'naming' projects. These had taken place in Birmingham, London and Portugal. Initially, for St Helens, many options were considered (streets, buildings and a theatre - were all initial possibilities). Once a naming project was imagined, the sense of finding an outside space to rename created greater potential than a building or a street.

Much of the land to be renamed was articulated as 'Lyons Yard Green Land' on Ravenhead Greenway, St Helens. The collective place names for the land had fallen out of parlance, and had little public meaning attached. Negotiations with St Helens Council to utilise the Ravenhead Greenway space were positive. The Council were supportive of potential future public usage where new possibilities could be launched. 
p. 254. Practice paper - Your Name Here: Renaming and reclaiming space. A new town centre vision within a renamed Park

\section{Methodology}

The methods used for researching this article are varied and included:

- Semi structured conversational interviews. Interviews were recorded and transcribed.

- Desk research.

- Observation and immersion in Heart of Glass activities from 2014 to present day.

Semi structured conversational interviews took place as follows:

- Telephone interview with the artist Joshua Sofaer on 31 May 2018.

- Numerous discussions and two walking and talking interviews with Director of Heart of Glass, Patrick Fox during 2014 to 2017. The most recent interview took place on 12 November 2018.

Participants in Your Name Here signed consent forms and further discussions and authorised consent took place to agree participation in the commemorative publication. Further usage of literature was rechecked with participants.

Drafts of this article have been sent to Heart of Glass and all work has been agreed with the organisation.

\section{A story of Your Name Here}

In May 2015 a three metre neon sign of the words 'Your Name Here' illuminated the front of St Helens Town Hall. The sign launched the arts project and called for residents to nominate a person with a strong connection to the borough, detailing their reasons as to why the identified land should be renamed after their nominee, and accompanying their explanation with a story, painting, photo, sound clip, video or object. The project took place over a five month period, with the call for nominations lasting for six weeks from 15 May to 26 June 2015. 
p. 255. Practice paper - Your Name Here: Renaming and reclaiming space. A new town centre vision within a renamed Park

\section{Images of the sign over St Helens Town Hall May 2015}
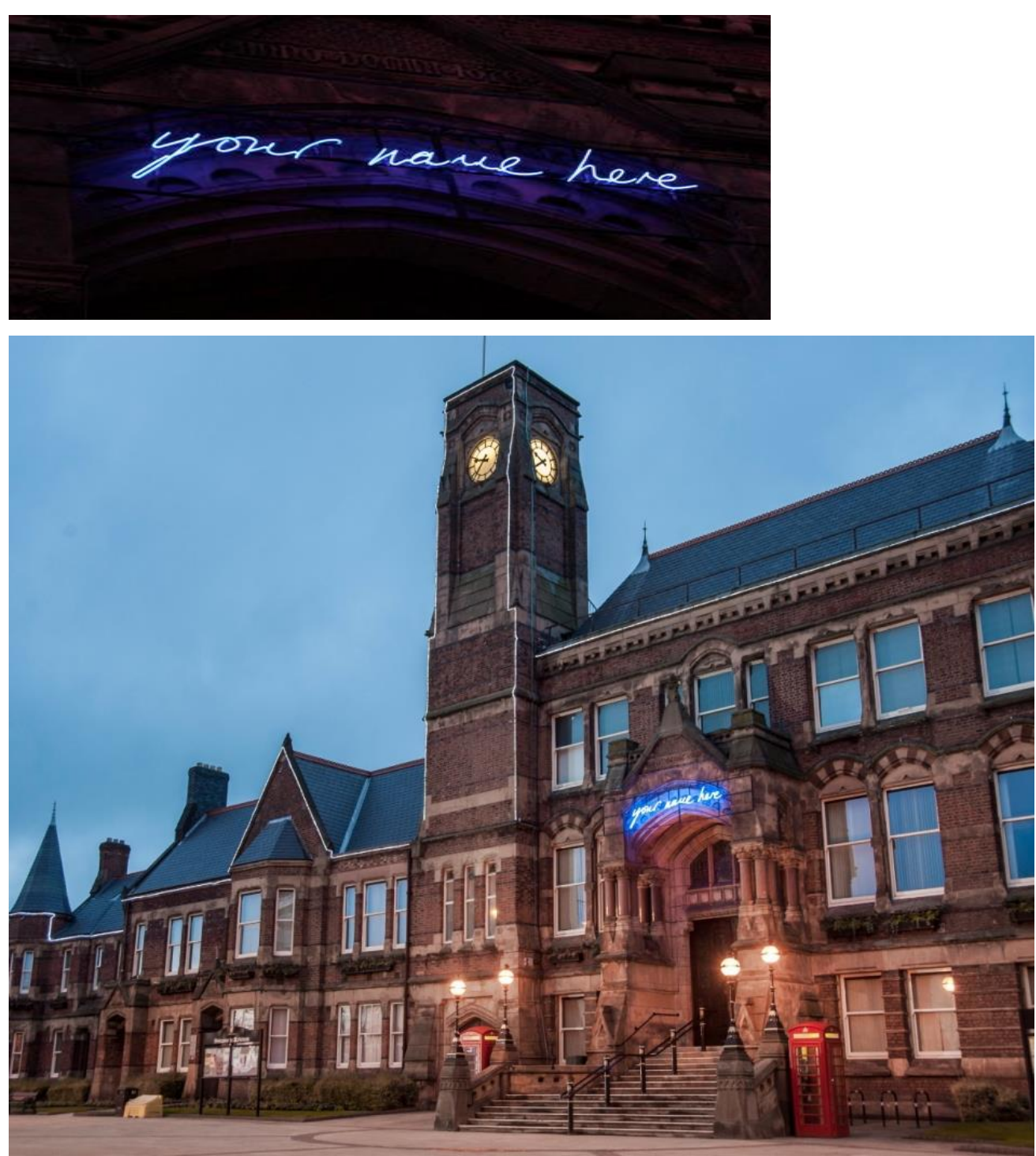

Your Name Here became quickly and widely known about throughout the borough. The signage at the front of the Town Hall was a significant seed to sow visibility and the beginnings of civic ownership. People saw the sign and began to talk.

The sign remained above the door of the Town Hall for the six week submission period. The town's newspaper, the St Helens Star distributed programme announcements for Heart of Glass and those announcements reached 70,000 homes. 100,000 fliers were distributed across the borough. The announcements advertised the chance to nominate someone to become the name of a park in St Helens. The announcements were highly visual and visible around St Helens. Alongside the newspaper inserts; a website, short film and billboard advertisement were created. 17000 hits were received in six weeks on the Your Name Here website. Over 500 people participated in workshops at schools, libraries, community centres, clubs and societies. 
p. 256. Practice paper - Your Name Here: Renaming and reclaiming space. A new town centre vision within a renamed Park

The website information and announcements asked:

Your Name Here wants to engage a conversation in St Helens about who we reward in society today, how we reward them, and to begin a discussion on a range of themes including citizenship, history, family, and civic pride.

What does it mean to be a citizen worthy of praise?

In today's celebrity culture, who do we want our role models to be?

Who are the important people we have forgotten?

Who among your family and friends have been most supportive and transformative in your lives?

Although anyone, from anywhere in the world could nominate someone, it was imagined that the winning name would have some connection to St Helens borough. The website stated:

In towns and cities across the country, streets, parks and buildings are named after people. Those selected are normally kings or queens, ministers of government, or those who have contributed something of great cultural significance to society...Rarely is there a chance to name a place after the ordinary people who live there...

\section{Billboard advertising for Your Name Here}

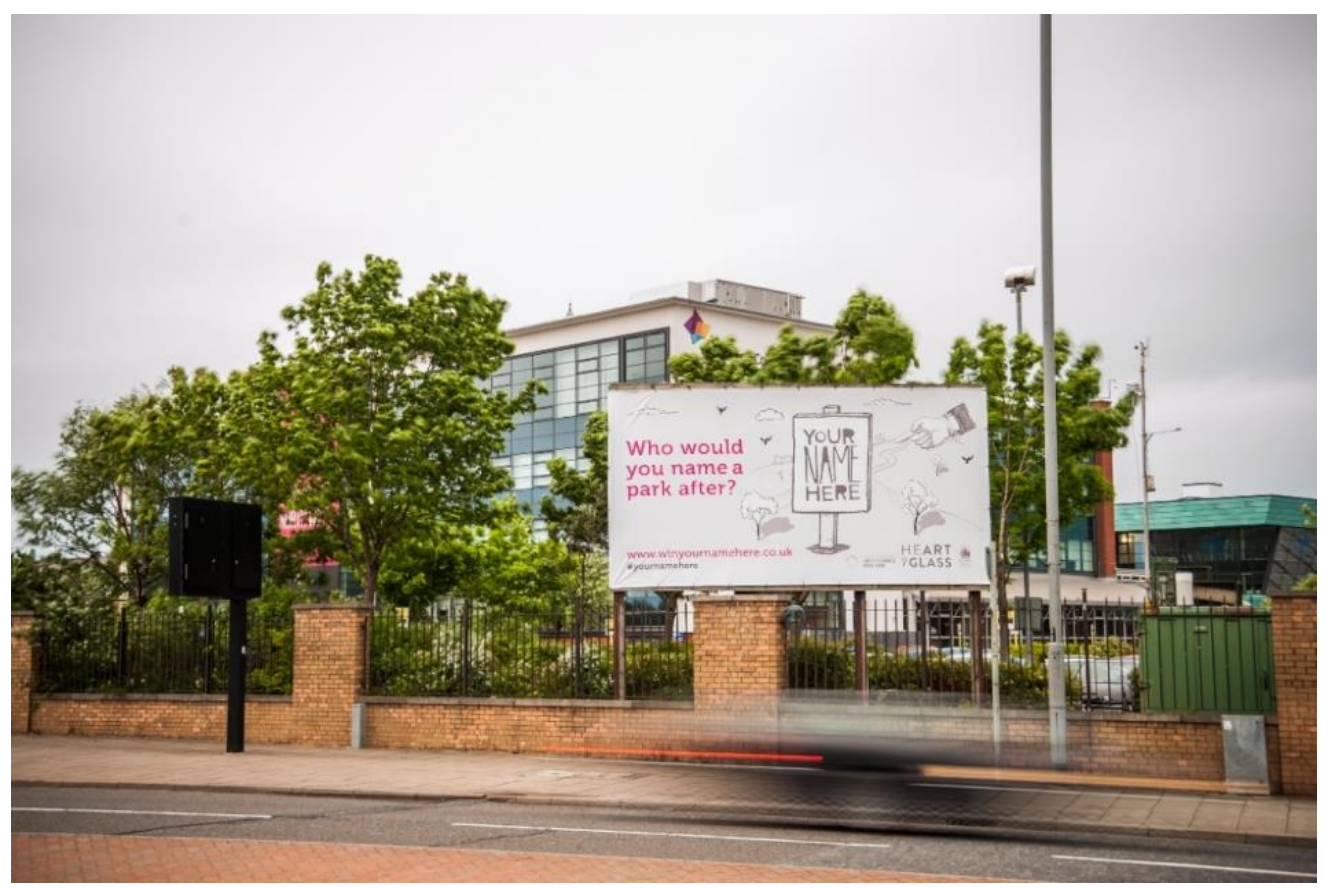


p. 257. Practice paper - Your Name Here: Renaming and reclaiming space. A new town centre vision within a renamed Park

The prolific response from the people of St Helens to the project was said to 'draw a portrait of the town'. Themes that emerged were, as the artist described:

...stories of forgotten figures from St Helens; people who have given to their community; nominations for loved family members and tributes to friends; memorials for those who have passed; and people who nominated themselves with very different reasons. Nominations were sometimes funny, often deeply moving, and always sincere.

Hundreds of people entered their stories and nominees and were judged by a panel comprised of Council Leader, Councillor Barrie Grunewald; actor and comedian Johnny Vegas; professional Rugby League player James Robie who plays with St Helens Saints; Corporal Andy Reid; Louise Latter from arts organisation FACT in Liverpool; and BBC Radio Merseyside journalist Jessica Robbins. The panel were chaired by Joshua Sofaer. Vera Bowes' self-submission of herself as a child, using her maiden name, was considered the most moving and appropriate title. Vera Bowes wrote:

\section{I am nominating myself as a child}

I can't forget the little girl who thought she wasn't wanted and how it affected my life.

My real Mum died when I was a baby. My Dad didn't want me after he re-married. So my Grandma brought me up with the others, but she died when I was four. After that my Aunt Rose looked after me. I called her Mam, thinking she was my mother. But at 15, she had to tell me the truth, because her husband didn't want to keep me.

I married and had five of my own children but lost two of them. My husband knocked me about and I suffered a nervous breakdown. The nurses had to teach me to walk and talk again - l'd gone completely.

\section{People tell me to forget the past, but they don't know what those years did to me}

The judges commented:

We were greatly touched by Vera Bowes' nomination of herself as a child, under her birth name Vera Page. For a project with the title, Your Name Here, it is wonderful to see someone who has tried to imagine what it would mean for them personally to have a park named after them, and to think of the opportunity as a way of confronting demons of the past. Vera's story of abandonment, despair and hardship may resonate with many of us; it is also uniquely her own. We want the naming of Vera Page Park to stand as a symbol for all of us who need to acknowledge the hurt of the past in order to heal.

When Vera Bowes found out she had won, she said: 'I can't believe all this is happening. It's like a dream. I keep thinking I'll wake up in a bit. I'm just an ordinary person. Fancy wanting my name for a park in St Helens. I'm proud, so proud.'

A celebration launch and opening of Vera Page Park took place on 5 September 2015. The event included a performance by St Helens Male Voice Choir, arts workshops and games including rugby tasters. 
p. 258. Practice paper - Your Name Here: Renaming and reclaiming space. A new town centre vision within a renamed Park

After the event, an eight page commemorative publication was published, and distributed as an insert into the St Helens Star on 10th September 2015. This publication allowed some of the Your Name Here nominations, as people, to be further acknowledged.

\section{Vera Page and the artist Joshua Sofaer at the launch on 5 September 2015}

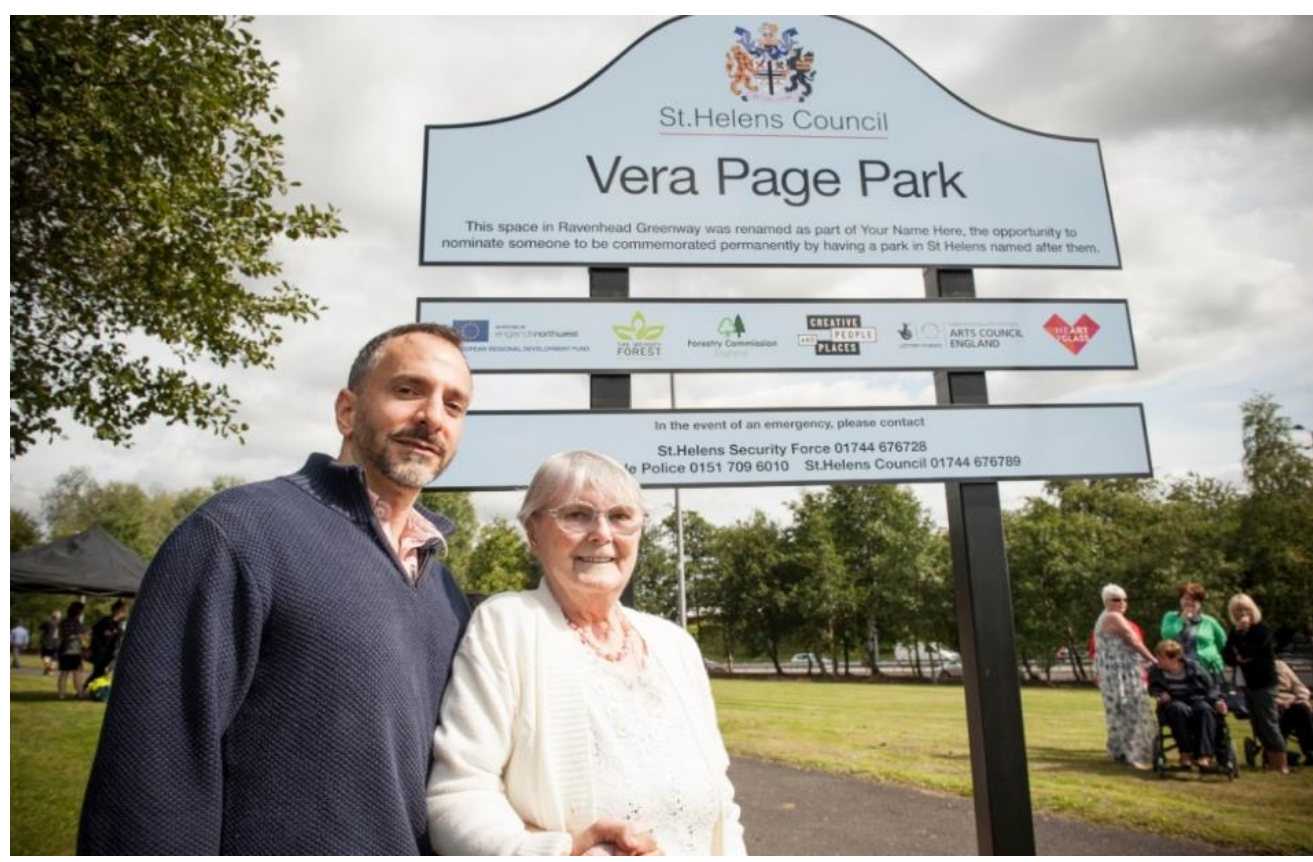

\section{Findings}

\section{Vera Page Park}

Renamed Vera Page Park in 2015 the land now forms the hub of St Helens Council regeneration plans for a new town centre. Heart of Glass and St Helens Council have a vision for the town becoming a centre for collaborative practice. In February 2017, St Helens Council launched their new narrative for St Helens. Built on culture, education and opportunity, not retail. Heart of Glass are working with the Council on embedding a culture of production into the town.

\section{Participants instead of audience}

As a condition of CPP funding, Audience Agency profiling took place. This profiling demonstrated that Your Name Here successfully engaged a wide range of participants from the whole of St Helens and further. Achieving a diverse spread of participation from all wards considered to be in the CPP-funded area. Audience Agency figures stated that 87 per cent of participants came from within the designated Heart of Glass Creative People and Places (CPP) project area. 13 per cent came from outside the CPP project area including neighbouring ward areas and further afield, (Plymouth, and 'further north'). In Audience spectrum profiling, almost half of the participants were from segments classified as low engagement and medium engagement. However, as Smith (2018) observed; participation goes beyond audience, ticket sales and 'engagement'. Smith argues that: 
p. 259. Practice paper - Your Name Here: Renaming and reclaiming space. A new town centre vision within a renamed Park

The profiling language can be at odds...where people are already, and can become, more than audience to arts activity... Profiling can provide useful information but drivers around audience do not necessarily correlate well with community driven or social change agendas.

If arts work is commissioned based on audience segmentation, then limiting beliefs can quickly form. Smith also argues that:

Thinking, writing and speaking in ways that counteract negative stereotyping, deficit-models and limiting beliefs necessitate a care with language which considers who and what may be being limited by the frameworks placed on it.

Your Name Here successfully built foundational blocks for the way forward from a very unstable starting position utilising innovative professional arts practices and a generous approach to engagement. New possibilities for collaborative commissions within a mass participation themed approach have become possible from experimenting with this project. The usefulness of Audience Agency figures is debated. Certainly for work in St Helens there are limitations in this type of approach and categorization.

In St Helens there is an irrelevance to the art literate audience of the art world. The language of the art world does not wash in a way that is described as liberating. As Sofaer commented:

People are open to engaging with ideas and they'll make their assessments.

As an artist working outside of a traditional theatre or gallery context that's extremely liberating and rewarding a context to work in and it opens out possibilities. The people of St Helens are open. They don't have a whole load of art prejudice. They are open to possibility. They will make assessments on the quality of an idea and their desire to engage with it rather than its artistic content.

\section{Sensitivity}

The success of Your Name Here partly depended on the artists' ability and Heart of Glass team's ability to negotiate and sensitively be able to 'manage' the process. Some submitted stories were very raw and included child bereavement. The judging panel was sensitive to future meaning-making in relation to a name and to the immediate history within St Helens.

The process of nomination and selection created a situation where expertise to sensitively manage the process of 'no' was critical. One of the biggest and most sensitive negotiations to tackle, was what Sofaer calls, 'the quality of the no'. Sofaer commented:

The publication became a very important part of the project. The quality of the no. That was phoning people saying: "you haven't been selected for the park", but we would love to include your entry for this publication... That also became a conversation, sometimes with two sets of phone-calls for each of those entries: the nominated (where applicable) and the nominees.

Your Name Here was a renaming project, yet Heart of Glass committed to the artist (Sofaer) rather than an idea of what the work would be. There was a necessary understanding, trust and sensitivity between artist, organisation, partners and people. 
p. 260. Practice paper - Your Name Here: Renaming and reclaiming space. A new town centre vision within a renamed Park

Artists working with Heart of Glass are artists with expertise and experience and are willing to push their experience. Esther Leslie, critical and cultural theorist, notes in Synthetic Worlds (2005) that "experience" and "experiment" share a linguistic root through the Latin experiri: to try thoroughly. "Expert" also shares this root. The sense of continuing to experience, to test, and to keep on testing, is demonstrated by Heart of Glass aliveness to the process of continuing to experiment and experience.

\section{Discussion}

How you make a call for interaction, how you engage people in a process, how you gather information, formed part of the artistic strategy for the project. Your Name Here projected a markedly altered image of people back to themselves, so that they could see or consider themselves in a different way. As an arts project Your Name Here heightened the visibility of Heart of Glass. Most importantly it was a project for the people of St Helens, and expanded notions of what might constitute art. If profile had been raised in a negative light, then the negotiations regarding further creative practices, which have taken place since, would not have been possible. The relationships between politics, art and locality and geography are increasingly complex. The project was at the forefront of a literal re-shaping of the cultural vision for St Helens.

There are now many places, people and artists Heart of Glass has worked with during its existence in St Helens. Cultural Geographer Doreen Massey argued that places, just like people, have multiple identities (Massey, 2005). Places are created by people, and it is through social practice, particularly social interaction, that place is produced within space. The Cultural Geographer Tim Cresswell (Cresswell, 2004) argued that space becomes place when meaning is attached.

Through projects, Heart of Glass create a space for dialogue, research and experimentation for artists and citizens in which the inter-relationship between people and place can be explored. In doing so, gathering and valuing diverse perspectives in the understanding, articulation and development of St Helens as a place. People, as active participants, both individually and within communities of place or interest, are central to Heart of Glass thinking and practice. Heart of Glass is supporting people as constructors of a narrative for St Helens, drawing out its 'DNA', and using that 'DNA' as a unique artistic platform for expression.

Heart of Glass does not have a dedicated production or exhibition venue and as Smith (2018) explores:

...instead utilising the wealth and challenges that come from finding alternative and often non-arts specific places to work with and within. This both extends as well as embeds arts practice outside of a traditional 'black box / white box' model.' The town becomes 'the venue'.

\section{Meaning-making of place through art practice with people}

It is important that Your Name Here is understood as an arts project and art work for the people of St Helens. The artist role afforded a legitimacy, a permission to think in a way outside of traditional remits on naming. Codes of governance, rules, or ways of working about naming in the public realm tend towards that which marks individuals who have made what is considered a significant contribution to the community. The difference with Your Name Here was that it inverted a hierarchy or perceived structure 
p. 261. Practice paper - Your Name Here: Renaming and reclaiming space. A new town centre vision within a renamed Park

and, allowed for the radical ordinary to be afforded space within the literal fabric of the town. As the website information stated:

The justification for naming a place after a person is generally that they are already celebrated. Their name is well known because of their status or what they have done. When naming a park after another kind of person, a person who is not known beyond their immediate social circle and who has led a quiet life, what kinds of criteria can you use to judge? What makes one person worthy of having a park named after them more than another?

... People will hold a range of opinions and yet more important than any one individual being singled out is the idea that we, as citizens, have the power to take control over our environment and leave our mark on it.

Vera's story was moving, However as Sofaer says:

In a way it was a profoundly ordinary story. In Your Name Here, the artistic possibilities of the everyday were considered, about the ordinary as being celebratory, and for people to think about the possibility that they could make a literal mark in perpetuity on their town without being the first person to do something considered culturally significant.

In Sofaer's other naming projects the accolade has been awarded to a person nominated by another. Vera Bowe's nomination is a nomination for herself as other, under a name she no longer takes; Vera Page.

\section{The Town Hall}

The Town Hall continues to be significant to Heart of Glass. Council representatives ranging from the Chief Executive to those in, for example, Regeneration or Public Health are met with by the Heart of Glass team on a regular basis. The signage for Your Name Here over the front door began a roll of events that take place here. New meaning is attached to the Town Hall through the Heart of Glass events that animate the space both within and outwith the building. Recent projects at the Town Hall include:

- With For About: Making a Meal of It. An event with, for and about socially engaged artistic practice and the negotiation of space.

- Lost Castles. Taking place outside the Town Hall. 250 people from St Helens created a large cardboard castle (a partial replica of St Helen's twin town Stuttgart's old Castle) with the French artist Olivier Grossetête.

- Split Britches, Unexploded Ordnances. Veteran award-winning live art performers Lois Weaver and Peggy Shaw performed a North of England debut of their show within the building. This show is usually performed in dedicated performance spaces.

\section{Conclusion: The Magic of Renaming}

Three signs now clearly demarcate Vera Page Park. A literal and metaphorical reshaping of the land has taken place through the renaming. It is a place that the citizens of St Helens can refer to and arrange to meet in. Not an unused space. There is some power now for long-term planning (and a certain magical element) within the strategy of 
p. 262. Practice paper - Your Name Here: Renaming and reclaiming space. A new town centre vision within a renamed Park

renaming Vera Page park. With partners, this project and other projects are engineering change in the make-up of St Helens in an extremely literal way, alongside the people of the town. Your Name Here has permanently changed the landscape of the town, and the maps of St. Helens are changing to accommodate the new name.

Your Name Here has established a sense of possibility in the people of St Helens that change or shift can happen, and there is a palpable sense of ownership of the town. The fabric of the town can change. This process was unusual in terms of the history of St. Helens or for any town. The ongoing procession of space into place and artistic practice continues.

In section two, context (above), this article observes that the instigation of Your Name Here came not from an in-depth study of the community, but from Heart of Glass's desire as commissioner and producer to articulate a possibility of what art practice could be. In section six, the necessity for expertise and sensitivity is also explored. This potentially forms the key learning of this project. The Heart of Glass way of working: trusting and committing to the proposition of a project with an experienced artist, is markedly different to an arts organisation relying on an audience base, one venue, or particular agenda, where the main driver is not necessarily engagement with people and place. With Heart of Glass practice, in the plethora of projects that have and are being developed, one encounters the proposition rather than the organisation, and the hyper-local practice develops from proposition and a 'with', not 'for', modus operandi.

Your Name Here also demonstrated that thinking around cultural production, economy and capital development in the town could travel a different direction. Heart of Glass remain committed to people and place rather than to a particular venue-based practice. New options regarding what might be fit-for-purpose capital development in the town can be considered and created. Development can speak to community need, as the effects of austerity and a crumbling community development sector continue to be felt. Utilising existing venues and public space in St Helens and co-opting any new capital spaces, might eclipse the allure of new less communal capital distractions. Alongside Arts Council England NPO (National Portfolio Organisation) funding, St Helens Council have invested substantially in Heart of Glass as the transformation of St Helens continues.

Vera Page Park now forms the hub of Council regeneration plans for a new town centre. 2018 is St Helens $150^{\text {th }}$ anniversary. Vera Page Park is the site for a proposed 'Pavilions' project. As artists Heather and Ivan Morrison who form Studio Morrison have committed to working with Heart of Glass on long-term residency for four years. Studio Morrison hope to work with voluntary groups to build structures that allow or create points of visibility for local creative communities within the Park. The artists are also working on the development of a skate park for St Helens which will link to Vera Page Park. The 2018 Heart of Glass programme of work shares a long term ambition with the local authority for the town to become a centre for collaborative practice.

Heart of Glass create a plethora of roles and points of entry when developing not only one successful art project, but strata of projects which together form far more than 'one-off' interventions into space. They coalesce and consolidate into real and measured developments of place. The iterative and cumulative processes of negotiation are pivotal to Heart of Glass working practice. A different rhythm is being formed amongst the static space of the retail park of Currys, PC World and Tesco, offering a viable part-replacement and new social rhythm to the senescent industry of Glass and the static industry of retail. 
p. 263. Practice paper - Your Name Here: Renaming and reclaiming space. A new town centre vision within a renamed Park

A rhythm has begun to beat with meaning making activities, people having experiences, and bringing others along. The fabric, the beingness of it, has begun to change, and there is a palpable ongoing procession of space into place.

\section{One of the three Vera Page Park signs before the unveiling}

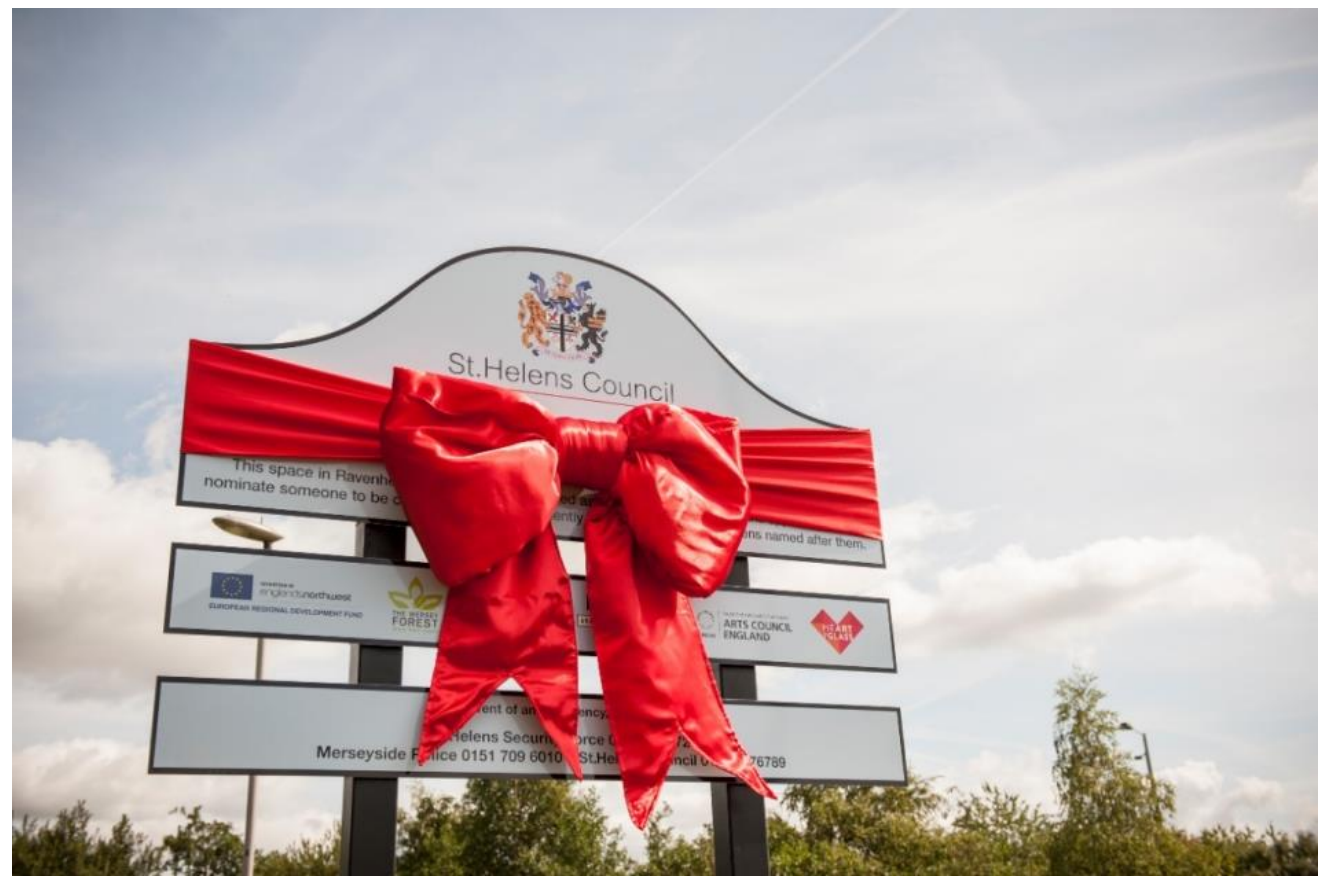

\section{Acknowledgements}

Thank you to Joshua Sofaer for taking the time to be interviewed on 31 May 2018.

All quotations from the artist are from this interview or are quoted directly from Sofaer's website.

Thank you to Patrick Fox at Heart of Glass for taking the time to walk and talk with me on various occasions throughout 2014 to 2017 and most recently on 12 November 2018.

Photographs by Stephen King for Heart of Glass. Also available on Sofaer's website.

*Correspondence address: Dr. Karen M Smith. Email: karen@smitharts.co.uk 
p. 264. Practice paper - Your Name Here: Renaming and reclaiming space. A new town centre vision within a renamed Park

\section{Bibliography}

Cresswell, T. (2004) Place: A Short Introduction. UK: Blackwell publishing Ltd.

Creative People and Places (2015) Creative People and Places homepage. [website] Available at: http://www.creativepeopleplaces.org.uk/ [Accessed: 01/06/2018]

Heart of Glass $(n, d$,$) Heart of Glass homepage. [website] Available at:$ http://www.heartofglass.org.uk/ [Accessed: 01/04/2015]

Leslie, E. (2005) Synthetic Worlds: Nature, Art and the Chemical Industry. London: Reakton Books Ltd.

Massey, D. (2005) For Space. London: Sage Publications Ltd.

Smith, K. (2018) Persistent Encounter. Exploring Social Capital and Creative People and Places. Creative People and Places. Available at: http://www.creativepeopleplaces.org.uk/our-learning/persistent-encounter

Sofaer, J. (n,d,) Joshua Sofaer homepage. [website] Available at: https://www.joshuasofaer.com/2015/09/yournamehere/

Sofaer, J. (n,d,) Joshua Sofaer Publications [website]. Available at: https://www.joshuasofaer.com/2015/09/your-name-here-publication/ [Accessed: 31/05/2018]

The Audience Agency (2016) Heart of Glass Year 2 postcode profiling report. Your Name Here [website]. 